学会長講演

\title{
日本のグロ一ハル私钼
}

第 75 回日本産業衛生学会 学会長 住野公昭

誰もがグローバルという単語を知っているし、グローバリゼーションを地球化と訳すこと はできる。現代用語として現われるのはほんの十余年前から、マスメディアに頻繁に使われ だしたのもここ 1 〜 年のことである。それまでの外国観（地球観の概念は今でも浮かばな い）は白人や黒人という人種や民族、あるいはアメリカやヨーロッパという国や地域を思い 浮かべるのではなかったろうか。長い間、我々が外国と接するときに抱く感覚は異文明観、 せまくは異文化観だったのではなかろうか。この巨大なテーマに応える資格は私にはないが、 以下、グローバル観を文明導入観としてとらえ、日頃感じていることを自身の言葉で緅って みたい。

\section{A 日本史的概锶}

日本（もちろん主体は日本人）が自国と他国を意識しだしたのは、おそらく 7 世紀の白村 江の戦いの時期ではないか。戦い前後、百済からの多数の渡来はさまざまの分野でシステム 化をもたらした。もちろんそれまで魏や晋に対して朝貢外交や仏教の伝来はあった。互いの 使節は言語、風習、文化の違いは認識したであろうが、別にへり下ることもなかったろう。 二国間交流より部族間交流の意識に近く、遗隋使の派遣もその延長である。

はっきりと他国の異文明、異制度を意識しだしたのは遗唐使の派遣以後であろう。朝貢外 交であっても律令制、宮造営を取り入れ、商業の発展と貨幣の流通を目にした。第一次グロ 一バル化の波である。しかし藤原氏の勃興につれて、平安朝の異国は蝦夷であった。米・土 地の執着から銭・交易に目を向けたのが平清盛が開いた日宋貿易である。しかし富を手にし たのは平家一門で、すぐ滅びた。

鎌倉武士は、改めて強く米・土地経済にしがみついた。その中で、第二次グローバル化の 波は元寇の役であった。元は侵略より貿易目的であったという解釈がある。風の吹き方によ っては、この時期に宗教や風習は“元化”され、火薬もワインも手に入れていたかも知れな い。

室町期はおおいに生産があがった時代である。食の余裕は商工業の発展を促し、それはま た文化・芸能の誕生をみる。大陸からのわずかな所作や種の輸入から独自の能や茶の文化を 生んだ。南北朝の乱、応仁の乱、戦国時代突入で民衆が右往左往のさなか、合間をみて足利 家は明との銭・交易（勘合貿易）に精を出し、北山・東山文化を残してくれた。一部都市の 自治の発生をみたのもこの時期である。

略歴 : すみの きみあき、1938 年神戸生まれ、1963 年神戸医科大学卒業、1968 年神戸大学 大学院社会医学系専攻修了、1968 年神戸大学助手 (公衆衛生学)、同年講師、1976 年助教授、 1979 年教授、2001 年神戸大学大学院医学系研究科教授（環境医学・公衆衛生学） 
第三次の波は間違いなく 16 世紀半ばの鉄砲とキリスト教の伝来であろう。権力者織田信長 をはじめとする戦国大名はこぞって南蛮文化に関心を持ち、遥かな異人種を知った。農民の 一部もキリスト教のデウスに感激し、それまでの浄士・極楽の観念のみならず、天国・楽園 の钼念を知ることになった。

信長は関所の撤廃、楽市・楽座の導入で商業・流通を促し、その背後に、米・土地経済の 脱却と中華以外の新文明の接触を見遥かしていたであろう。しかし挫折した。後継者の豊臣 秀吉は検地や兵農分離まではよかったが、晚年狂気に走り、世界の仲間入りに失敗した。

徳川13 代まで、歴史上もっともローカルに徹した期間であった。分厚い布団に潜り込み、 ほんの隙間から清国とオランダの空気を取り入れた。しかし中では暫時の安眠後、布団を勢 い良くはねのける熱気がこもりだしていた。農民が米・土地に縛られる一方で、町民は加工・ 流通業に精をだした。商業の発達は合理的思考を育て、また各藩がこぞって特産品を奨励し 競争意識が芽生えた。無意識であるが、次の波の備えにはなった。外でがやがやと隣の家が 潰されそうという情報があっても目が覚めず夢現つであった。布団のなかでは独自の文化が 花開いていた。その遺伝子は現在の我々に濃厚に引き継がれている。

「起きろ」とどやしつけながら摇さぶったのはペリーであった。19 世紀半ば、第四次の大 波である。太平の夢醒めた人々は、初めて外国文明の息を吸い世界を意識し、同時に国家・ 国民を知った。刀と髹を放り、急いで洋食を食い、洋服に着替え、教えを請いに駆け出した。 寒村であった神戸もその出入口となった。

翻訳日本語が誕生し、太陽暦の採用(1872)で世界と同日に並び、メートル法(1885)も学んだ。 その咀嚼力は結構すばらしく、脳は発達し血管も新生し、各臟器が機能すると運動能力、闘 争能力も増加し、新兵器の使い方も知った。幼児から成人までの成長は他人から見て驚異で あった。近隣に対し喧嘩も吹っかけ、居座ったりもした。しかし一人合点で行動したため老 化も早く、1945 年(昭和 20 年)、全身血みどろとなり、一部の機能を残し植物状態となった。

機能不全からの回復もまた早く、臟器の提供を受けてそれを入れ替えるように民主主義、 基本的人権、自由と平等などが機能しだした。第五次の波にほぼ全身吞み込まれた。国際組 合にも参加が許された。しかし骨䯣ともいうべき日本文化は廃れることなく、一部は輸出さ れて禅や柔道のように愛用されているものもある。しかし移植された分量からみれば微々た るもので、作り方を教わった加工品を大量に安く買わせて高度成長をとげた。

オリンピックや万国博覽会の頃から“国際化”が叫ばれ、計画や評価は下手ながら、世界 に向けて援助交際や支援事業に精を出しだした。これまでは二国間にしろ多国間にしろ、お 互いに国ぎわを意識してきた。他国の文化も尊重し、こちらの価値観を強引に押し付けたり はしなかった。しかし 1980 年以降、経済問題からボーダレスが、環境問題からグローバルが 言われだし、手法や基準が統一の方向へ動きだした。産業保健分野にもへルスマネジメント システム、危機管理、グローバルスタンダードが議論されだしている。

穷かにとみせていた波は、2001 年9月以降、“この指たかれ”式に旗幟を鮮明にすること を超大国から要求された。私にはグローバル側に立つかローカル側に味方するか問われたよ うに思う。それもほとんど議論する間もなく、“指にたかった”つもりが貢献りストには載せ てくれなかった。第六次の波である。 
B 兵庫・神戸の文明の接点（神戸開港三十年史と兵庫県風土記から）

「武庫の水門は文明輸入の門戸なり。」三韓からの朝貢船は武庫の地に集い、亭館を圈き方 物を献じ、仁徳朝の 100 年で日本国民の心性は中華文明の感化を受け、文質涁彬、礼儀の気 風など様変わり、その武庫が今の兵庫という。大輪田(大和田)泊の名称は古いがなぜ兵庫かに ついては定かでない。

平清盛は福原遷都の前、兵庫の津に経ヶ島を作り日梁貿易で富を得たが、遷都 2 年後、1183 年に灰燼に帰した。鎌會後期に旧に復したかにみえたが湊川合戦(1335)で村民は去った。秀吉 時代、百貨輻輳の商業大いに栄えるまで、歴史から消える。

天明年間(1781)諸国趈船の往来はげしく、吳越人が巷を行き交い、周辺の戸数 5,500、人口 2 万、持船 800 艘弱とある。

幕末の神戸には、六甲山麓の水車を利用した酒造業、絞油業、製粉業(素麺)と兵庫に海運業、 造船業があった。慶応 3 年 12 月 7 日 (1868 年 1 月 1 日) 神戸開港。諸神天下る歓迎風景と物 情騒然の雰囲気があった。慶応 4 年 1 月 11 日、神戸事件勃発、砲声響き外国占領地の状をな し、住民は近村に逃げた。

以後、居留地の発展と諸工業の発達とあいまって、神戸は文明の門戸としての役割を果た すことになる。神戸から全国に発信した事項を列挙すると、活動写真、水族館、回教寺院(モ スク)、ゴルフ、岩登り、移住・移民、マラソン大会、パーマネントなどである。

社会・労働面では、大正期の川崎造船所の労働争議の結果として日本初の 8 時間労働制の 実施、神戸購買組合と灘購買組合（現コープ神戸）設立、賀川豊彦指導による労働争議や農 民組合結成などがある。

そして阪神・神戸から世界に向けて発信したのはカラオケ、最新は 1995 年の阪神・淡路大 震災である。

こうしてみてくると、我々は、祖先も含めて、海外を意識し出かけるのは文明の輸入のた めであって、ほんの一時期を除いて文明・文化の輸出や発信に意を用いたことがなさそうで ある。明治期には、日本にも“源氏物語” “関ケ原の合戦” “浮世絵”があるぞと喧伝してく れた外国人もいたが、研究対象以上にはならなかった。

第一、日本には世界史に冠たる文明の誕生があったのか、それより日本がなくても世界史 にはほとんど影響がなかったのでないかという極端な見方がある。エジプト、中国、インド がなければ世界は今のようではなかったし、若い国アメリカがなければ世の中暗く淋しかっ たであろう。過去 2000 年、我々は諸外国にお世話になりっぱなしであった。地球化の時代、 今後 100 年でも 500 年でも通じる大発見や発明、平和を阻害する要因を予防するような新価 值観などを、我々日本人の手で生み出し発信したいものである。 